\title{
DIMENSIONS OF LINGUISTIC OTHERNESS: PROSPECTS OF MINORITY LANGUAGE MAINTENANCE IN HUNGARY
}

\author{
(Received 18 January 2006)
}

\begin{abstract}
After some preliminary remarks on minority policy and potential impacts of Eastern enlargement of the EU in Central and Eastern Europe, we give a brief overview of the basic characteristics of the sociolinguistic and ideological context, as well as of minority policy and legislation concerning autochthonous minorities in Hungary. In the next section of the paper we introduce the results of a national sociolinguistic language shift survey conducted by the authors, focusing here on the comparative data on language and identity of the six communities studied. This is followed by a detailed analysis of the attitudes of the Romanian and Serbian communities to mother tongue and national identity. Research results presented in our article demonstrate that the language-identity link is not self-evident: these concepts need to be separated if real linguistic (and ethnic) arrangements are to be understood. Analysis of the 'architecture' of the respective ethnic identities and the role of minority languages in the construction and negotiation of identities revealed that the native language plays different roles within the studied communities.
\end{abstract}

KEY WORDS: autochthonous minorities in Hungary, comparative data, Eastern enlargement of the EU, language and ethnic identity, language maintenance and shift, language policy

\section{European Enlargement, Minority Languages and Language Policy in Central and Eastern Europe}

One of the basic principles of the European Union is to support cultural, linguistic and regional diversity, which, in principle, should include the special identities of national minorities. Questions about the legal protection of regional and minority languages have regularly appeared on the European agenda: for many years various political and civic actions have centred upon the legal regulations applying to minorities. Additionally, there are several EU policies which may also affect the situation of minorities in the Member States, though often in an indirect way (Vizi, 2003). However, these programmes alone are not sufficient to deal effectively with problems confronting minority languages: they cannot guarantee on their own that minority languages will be preserved. The 
accession of the new Central and Eastern European Member States opened up new prospects while at the same time creating new problems for the enlarged EU with regard to protection and maintenance of minority languages.

There are a number of features characteristic of the region that impact differently on minority languages and on the implementation of supranational policies. Some of them are listed in EUROMOSAIC III concerning the new Member States. The high occurrence of linguistic proximity between the languages in contact, the fact that most regional and minority languages spoken in the new Member States are also state and/or official languages in bordering countries (the 'complementary' status of the languages), diverse interstate relations (whether the kin state is part of the European Union or not), the average $60 \%$ of the Roma population in the New Member States in comparison to the $37 \%$ rate at the European level, the high geographical dispersal of minority language groups etc. are idiosyncratic factors which suggest that many internal as well as external characteristics of linguistic diversity previously identified for the Western part of the enlarged EU cannot be taken for granted in its Eastern regions.

Another important region-specific feature is that during the communist period, research on linguistic minorities was hardly encouraged in the countries of the Soviet bloc. Therefore, available research is rather heterogeneous in terms of quality, quantity and areas covered. During that time, researchers worked in relative isolation with only sporadic regional and international professional contacts. Although there are significant results of these research activities (written for the most part in the respective national languages), very few of them have become part of international academic discourse.

A further factor common to East European Member States and candidate countries regarding the role of researchers and research results in policy making is the fact that academics studying linguistic minority issues as a group have had extremely limited impact on the initiation and formulation of minority policies (in the processes of status, acquisition and prestige planning, in the development of programmes for the education of linguistic minorities, or elaborating the curricular content of minority education). Their ability to shape policy has rarely extended beyond a contribution to implementing the agenda set by central government politicians. 
However, it is clear that we are witnessing a radical decrease in the use of minority languages and 'rapid language shift'. There is a need first to provide a systematic review of the state of linguistic minorities of the region - countries which are simultaneously characterised by a post-communist political, sociological and cultural heritage and by an immense and ongoing political-ideological restructuring due to a new, expanding Europe - and secondly to develop a new body of research conducted by professionals free from all bias both on common and on particular characteristics of linguistic minorities and their situations in Central and Eastern Europe. This would provide much needed evidence and feedback for the current minority policy and programmes about how they succeed or (more often) fail to meet the needs of linguistic minority groups.

An important starting point of the present article is Spolsky's proposal of appropriate steps to approach language policy:

In looking at the language policy of a state or other unit, it is appropriate to start off with an effort to capture the complex language situation. [...] A second step involves attempting to identify the relevant beliefs about the potential values, symbolic as well as pragmatic, of the varieties. With this background, one can search for the specific language-management and language-planning decisions that have been made and ask if they have in fact had any effect on language beliefs or on language practices. (Spolsky, 2004: 218).

\section{Researching Language Shift within Autochthonous MiNORITIES IN HUNGARY}

\section{Introduction}

In recent years a considerable linguistic, sociological, ethnographic and legal literature has developed dealing with autochthonous minorities in Hungary (Bartha \& Borbély, 1995; Borbély, 2001; Erb \& Knipf, 1999; Gal, 1993; Garami \& Szántó, 1992; Gyivicsán, 1993; Karády, 1990; Réger, 1979). Although this research provides a wealth of data originating from different bilingual speech communities, comparative sociolinguistic research on the linguistic practices or language shift patterns has been less thorough. Between 2001 and 2004 the authors conducted the first national sociolinguistic survey on linguistic and social change in six linguistic minorities with non-Hungarian ethnolinguistic backgrounds entitled "Dimensions of linguistic otherness: Prospects of minority language maintenance in Hungary", with a special focus on local models of 
language shift and maintenance (see Bartha, 2003). Besides the Romanian, Slovakian, Serbian, German, Romani and Boyash minorities, culturally Deaf people as members of a highly discriminated linguistic community were also included in the analysis. Our comparative research combines theories and methods of quantitative sociolinguistics, linguistic ethnography, social psychology and the language ideology approach. In the following sections of the paper, after having clarified the notion of language shift, we will give a brief overview of some sociolinguistic and ideological questions, as well as of minority policy and legislation concerning autochthonous minorities in Hungary. In the third part of the article, we will present and compare data on attitudes to mother tongue and nationality identification among the Romanian and Serbian communities.

\section{Theoretical Background}

Sociolinguistic aspects of language shift and maintenance are approached here in terms of social, linguistic and ideological changes: ways of acting in and responding to a dominant, and often hegemonic, social world in a majority language context (see Bartha, 1999).

In many multilingual sociolinguistic situations where bilingualism of a sociologically non-dominant group is being transformed into a new, monolingual situation, language shift is, as Gal (1996: 586) claims, "a dramatic instance of how social function, sociopolitical context, and cultural evaluation can affect language".

Many of those studying language contact identify exclusively one particular case of repression of a minority language as shift, a type that may be called 'gradual language shift' (see Fase, Jaspaert, \& Kroon, 1992: 3). It should be emphasized, however, that a linear, unidirectional depiction of the process often leads to stereotypical interpretations. Opting for a more complex and multi-level explanation, rather than a formal/informal axis, our description is reinforced by examples in which repression of a language is reversed and turns to the opposite direction on the one hand, and the diverse networks of the same community can respond differently to the social, economic, political and cultural changes, on the other.

A central issue of many studies on language shift is the correlation between social determinants and their effects on language. We focus (as Gal did in 1979: 3) on the process of language shift, as well as on the questions Kulick (1992: 9) raises criticizing the explanatory power of macrosociological factors: 
to evoke macrosociological changes as a 'cause' of shift is to leave out the step of explaining how such change has come to be interpreted in a way that dramatically affects everyday language use in a community. If the investigation of language shift is modified to include such steps, the question that then must be answered is: Why and how do people come to interpret their lives in such a way that they abandon one of their languages? [Hence] the study of language shift becomes the study of a people's conceptions of themselves in relation to one another and to their changing social world, and how those conceptions are encoded by and mediated through language.

Most sociolinguists seek to answer the question whether there is a general model that can be applied to predict the outcome of the process in different communities living in different social and linguistic circumstances. It can also be relevant to consider whether one can predict the intensity of the process, in cases where the symptoms of language shift are clear. Another important task is to explain why a seemingly identical arrangement in one situation favours language maintenance, whereas it leads to language shift in another; not to mention situations in which an already finished or almost completed language shift process takes a turn, and the language that until then was used only to a limited extent, or not used at all, partially or completely regains its former functions ('reversing language shift', Fishman, 1991).

However, in spite of the rich sociological and ethnographic literature on language shift, maintenance and revitalization, there seems to be a dearth of comparative research on these processes. We argue that language shift can be more adequately interpreted if cross-community differences of linguistic practices and ideologies are taken into account, even in the case of the 'same' language pair, in seemingly identical sociolinguistic settings.

\section{The Situation in Hungary}

Hungary has been marked by cultural diversity for centuries. There are very few Hungarian families in the country whose ancestry does not include people from a non-Hungarian ethnic background. Since its beginning, Hungary has been a multiethnic state, and numerous communities have lived in its territory since the foundation of the state one thousand years ago. The modern ethnic and linguistic arrangement of the country was basically established after the population had been decimated and moved during the Ottoman occupation, resulting in extensive spontaneous migration, and after the controlled resettlement of people in the 17th-18th centuries. Towards the end of the 19th century, non-Hungarian communities 
living within the borders of the country comprised more than $50 \%$ of the total population (see Figure 1).

At that time British historian, R. W. Seton-Watson (1908: 3) referred to Hungary as "the most polyglot state in all Europe". In 1920, the Peace Treaty of Trianon resulted in a linguistically more or less homogeneous state: the Dual Monarchy collapsed after World War I, and independent successor states were created around Hungary (see Figure 2). (For the linguistic and ideological complexity of the present-day sociolinguistic situation, see Gal (2006). Some 33\% of Hungarian mother tongue speakers (3.3 million people) found themselves outside the newly demarcated borders, while Hungary's national minority populations declined from $45 \%$ in 1910 to $7.9 \%$ in 1930. According to different estimates, autochthonous minorities today represent not more than $10 \%$ of the population.

The Trianon Peace Treaty created a unique political and linguistic arrangement in the Carpathian Basin; therefore, the linguistic situation and the different roles of the languages in contact can properly be analyzed as part of a cross-national, East-Central European language ecological system. Trianon can be regarded as a linguistic trauma: it enhanced and re-contextualized the one state-one nation-one

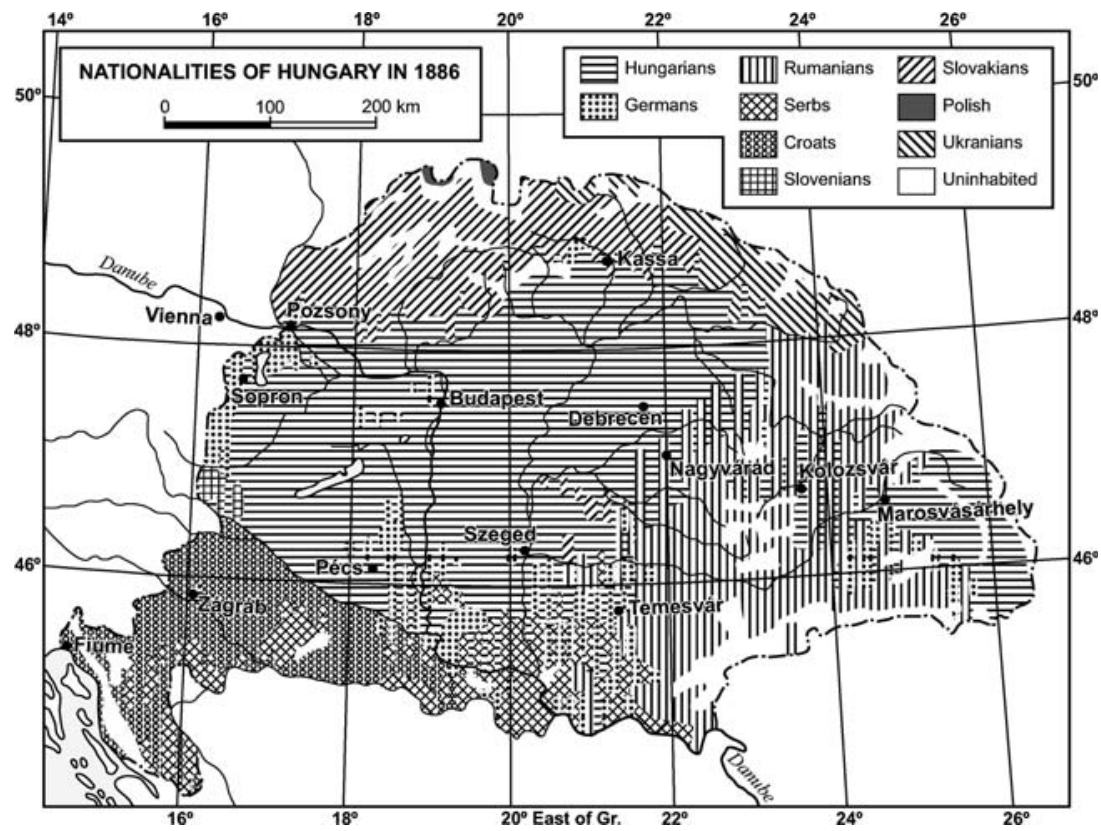

Figure 1. The Nationalities of the Kingdom of Hungary in 1886 Source: http:// www.historicaltextarchive.com/hungary/map5b.gif. 

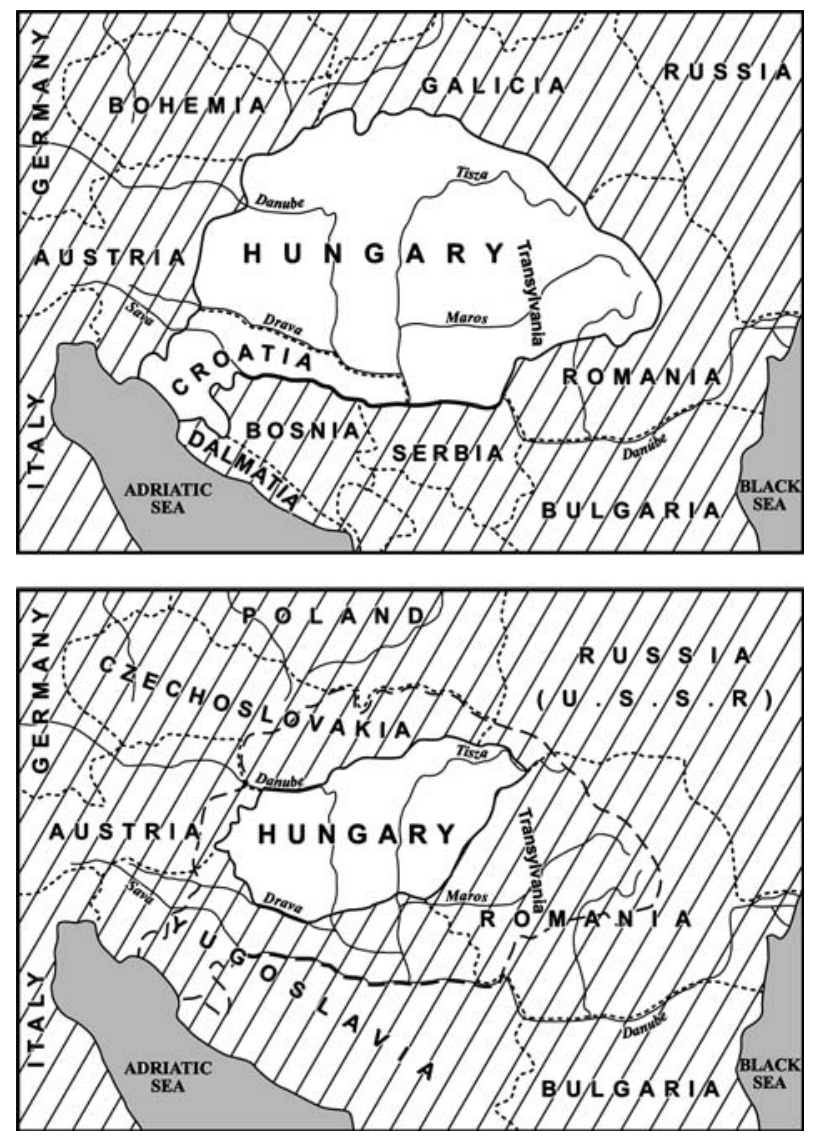

Figure 2. States of the Carpathian Basin before and after the Treaty of Trianon. Source: http://www.historicaltextarchive.com/hungary/map1.gif

language idea, the Herderian concept of nationalism that considers monolingualism as a marker of allegiance to the State. Monolingualism in another language, however, or even active bilingualism of the minorities was viewed with suspicion.

The curricular content of basic education, as far as ethnic, political and economic geography in Hungary is concerned, is an obvious sign of these ideas. As in many other cases and as a result of the ideological bias against minority mother tongues in schools pupils view minority languages and especially their local, non-standard variants in a negative light: they dramatically lower the symbolic as well as the economic value of the languages (Dorian, 1981: 28-29). Although conditions have improved considerably since the collapse of the communist régime in 1989, many of past 
and even present linguistic and social practices and language planning activities can only be interpreted in this context (for the analysis of the post-communist transition see Bozóki, Körösényi, \& Schöpflin, 1992; for a detailed analysis of minority policy see Győri Szabó, 1998).

According to the 1990 census, within a population of $10,374,823$, a total of 232,751 persons signalled minority affiliation, and 137,724 claimed that their native language was one of the national or ethnic minority languages (Czibulka, 1991). The 2001 census announced similar rates (see Népszámlálás, 2001, 2002; see Figures 3, 4).

However, many researchers and minority organizations estimate the actual proportion of national or ethnic minorities to be much larger: individual groups are reckoned to comprise from a few thousand persons up to nearly half a million ${ }^{1}$. The considerable differences between estimated and declared figures in the last few decades can be attributed to the historical, political, ideological, and psychological atmosphere of state-socialism with respect to the Marxist-Leninist definitions of 'minorities' and 'ethnic difference' in the region.

The first significant steps towards the codification of collective minority rights in Hungary were the amendment of the Constitution in October 1989 and Article 68 added to this document in

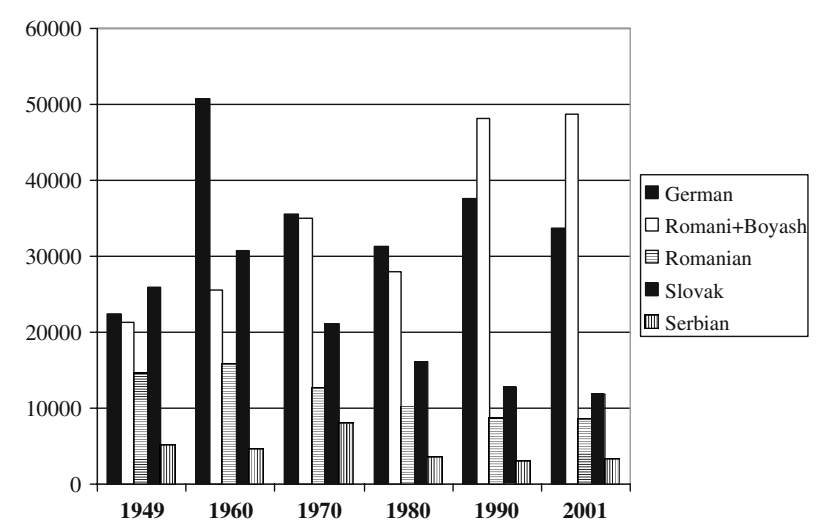

Figure 3. Mother tongue population of six linguistic minorities (according to census data 1949-2001).

${ }^{1}$ According to different expert reports the actual number of minority citizens is
significantly higher (up to $7 \%$ ) than official figures indicate (Vermeersch, 2004: 5). 


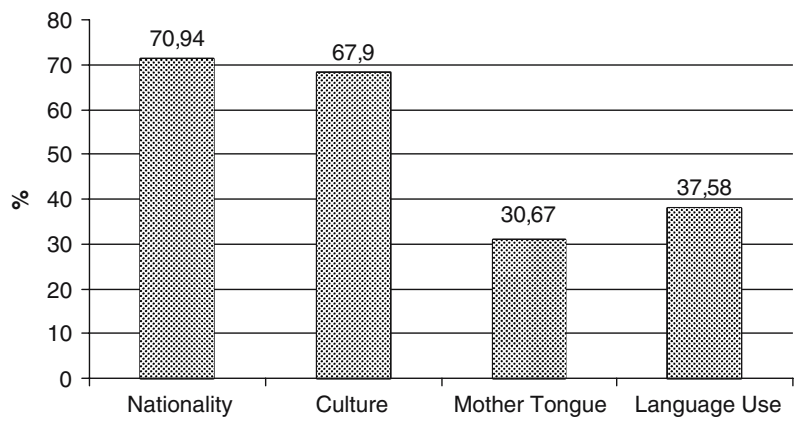

Figure 4. Minority affiliation (Four Identity Categories; Census of 2001) $N=442$ 739. Source: Tóth and Vékás (2004): 9, Table 6.

$1990^{2}$ The new Article 68 contains five paragraphs concerning the status of minorities in the state (Paragraphs 1,2), their political representation (Paragraph 3), their right to form self-government (Paragraph 4), and the stipulation that minority legislation requires a two-thirds majority (Paragraph 5). More importantly, in accordance with a new policy of 'cultural differentiation' in the transitional period of the country, as well as international human rights standards, and according to the basic principles of the EU ${ }^{3}$ supporting cultural, linguistic and regional diversity, which, in principle,

2 The Constitution of the Republic of Hungary Article 68 states: (1) The national and ethnic minorities living in the Republic of Hungary participate in the sovereign power of the people: they represent a constituent part of the State. (2) The Republic of Hungary shall provide for the protection of national and ethnic minorities and ensure their collective participation in public affairs, the fostering of their cultures, the use of their native languages, education in their native languages and the use of names in their native languages. (3) The laws of the Republic of Hungary shall ensure representation for the national and ethnic minorities living within the country. (4) National and ethnic minorities shall have the right to form local and national bodies for selfgovernment. (5) A majority of two-thirds of the votes of the Members of Parliament present is required to pass the law on the rights of national and ethnic minorities.

3 Although legal changes in Hungary started in the late 1980s, alongside the process of political and economic transformation, Vermeersch (2004: 7) points out the role of the potential strength of the EU's strategy of 'membership conditionality', "which directly linked minority protection with EU membership", referring to the attempts "the EU has made since 1993 to induce policy change and legislative reforms in the candidate states by making entry to the EU dependent on compliance with a number of political and economic demands." Typically, legislation on minority protection in the new member states was developed as part of an effort to meet formal requirements of EU accession. Currently, significant differences exist between the rights of minorities in countries of the region, and a number of linguistic minorities are not recognized as such. 
should include the special identities of national minorities, Act LXXVII on the Rights of National and Ethnic Minorities was passed by the Hungarian Parliament in July 1993. The Act applies to minorities that have lived in Hungary for at least a century ${ }^{4}$. Furthermore, if at least 1,000 persons declare themselves to belong to a minority not listed in the Act, they may initiate legal procedures in order to become a recognized minority. Bulgarian, Roma, Greek, Croatian, Polish, German, Armenian, Romanian, Ruthenian, Serb, Slovak, Slovene and Ukrainian ethnic groups are defined as national or ethnic minorities ${ }^{5}$ native to Hungary according to this law. However, through the privileging of indigeneity on the one hand, and the enforcing of a disability paradigm on the other, immigrant languages and Hungarian Sign Language are not covered under the provisions of the minority language act.

Although this law and further legal instruments in principle assigned many linguistic human rights ${ }^{6}$ (Borbély, 2002: 61-65) to 13 minorities, their bilingual status and the ethnolinguistic and cultural differences of their members have in practice been neglected in many

4 The Minority Act states that national and ethnic minorities are defined as: "All groups of people who have lived in the territory of the Republic of Hungary for at least one century, who represent a numerical minority in the country's population, whose members are Hungarian citizens, who are distinguished from the rest of the population by their own languages, cultures, and traditions, who demonstrate a sense of belonging together that is aimed at preserving and protecting the interests of their historical communities" (Chapter 1, Section 1, Subsection (2)).

5 The Hungarian terminological distinction between 'national minority' and 'ethnic minority' rests primarily on whether a minority has a 'mother country'. The Roma do not, hence they are called an ethnic minority. Most of the national and international arguments against the law were formulated particularly in terms of the Roma community. It might be of interest to mention that the first version of the document did not refer to Roma communities at all.

6 The Act establishes individual and collective minority rights in the areas of selfgovernment, language use, public education and culture. Among collective rights, the law also states that minorities have the right to form local and national selfgovernments, with the aim of guaranteeing cultural autonomy. As such, minority self-governments have rights enshrined in law allowing them to make decisions in their own spheres of autonomy on the foundation, taking over and maintenance of institutions, particularly in the areas of local education, the local printed and electronic media, and the nurturing of traditions and culture. (see Borbély, 2002: 61-70) 
professional and public domains ${ }^{7}$. Language policy in Hungary (and in other new Member States) is theoretically based on the notions of equality between citizens, of freedom of identity choice etc., and hence between languages too, as essential symbols of ethnic identities. Nevertheless, these rights are not always respected in practice. There is often a significant gap between declared linguistic minority policies (including ratified international legal instruments) on the one hand, and their de facto implementation on the other.

This is one important reason why, in most of the 13 minority groups in Hungary, language shift from the minority language to Hungarian is advanced or has been completed.

Minorities' attitudes towards their own language and ethnic group were not altered enough so as to influence the revitalization of these languages or reinforce their use. Recent changes in respective census figures, however, reflect the re-evaluation of the relative power and market value of the minority language and Hungarian in a new 'Pan-European political-economic' context (Gal, 1995: 101). Gal's analyses of symbolic associations of Hungarians and Germans in Bóly, Southern Hungary, gave a detailed account of this recontextualized comparison. Another remarkable factor of the rapid assimilation process is a highly conspicuous level of double standards with respect to the way in which the claims of Hungarian minorities living outside Hungary and linguistic communities within the country are actually recognised. As a consequence, it seems that in the new Europe English and German are becoming especially important among the younger generations of minorities, whereas (other) minority languages in Hungary are seriously endangered. ${ }^{8}$

\footnotetext{
${ }^{7}$ Commission Report 2002 (Hungary) of the European Commission in the chapter on Minority rights and the protection of minorities revealed that: "The Ombudsman for the Rights of National and Ethnic Minorities monitors the implementation of minority rights and investigates complaints of violations. In 2001, some 453 new cases (431 in 2000) were registered at the Office of the Ombudsman, of which 292 (291 in 2000) affected the Roma Community. Most cases targeted the activities of local governments (118), police (49) and courts (31). Around two thirds of these cases were followed-up by the Ombudsman." http://www.fifoost.org/ungarn/EU_ Hungary_2002/node24.php)

${ }^{8}$ Older people mostly preserved their own minority language, and kids are mainly Hungarian monolinguals. In $1989-1990,92 \%$ of the 43,300 pupils studying in minority schools were pupils of a type of school which provides no more than the teaching of the minority language and literature in the pupils' mother tongue, in four to six periods a week. The domain where the minority language is used in Hungary is the home, whereas conversation with friends and schoolmates, as well as shopping, tend to be bilingual or more often Hungarian.
} 
Not surprisingly, among national minorities, the German community is unique ${ }^{9}$ in terms of its increasing ethnic and mother-tongue population; grassroots revitalization movements are in progress. Furthermore, Germans in Hungary constitute a linguistically, culturally, ideologically, and socio-economically diverse community, therefore the process of language shift in German-Hungarian settlements has not occurred in a uniform way.

However, even though we have witnessed a radical decrease in the use of minority languages and 'rapid language shift' might be an appropriate general cover term for ongoing linguistic and social changes within these minority groups, each community has its own local interpretations and beliefs about the new political-economic and ideological context.

${ }^{9}$ At the other extreme, the position of the Roma, the sole officially defined ethnic minority in Hungary is very specific. As many sociologists and cultural anthropologists emphasize: "The Roma are not a uniform ethnic group, but rather a collection of distinctive groups that can be readily distinguished ethnographically and socially. Historical, political, and economic factors have created enormous diversity among the Roma in Central and Eastern Europe. This diversity often makes it difficult to decide exactly who should be considered a "Roma"' (Roma Education Working Group, 2001). The numbers of the Roma and their mother-tongue figures have been debated for a long time. Sociolinguists estimate their number to be around 400,000, while according to Kemény, Janky, and Lengyel (2004), they comprise 600,000 (6\%) of the country's population. István Kemény, a sociologist, who has studied the Roma in Hungary for decades, estimates that Roma children comprise about $8 \%$ of the population in elementary schools. According to his first-linguistically doubtful - survey carried out in 1971, only about $21 \%$ of Roma were bilingual at that time (Kemény, Rupp, Csalog, \& Havas, 1976). The bilinguals include Romani-speakers (about 100,000), over half of whom speak the Lovari dialect, and the Boyash Romanies (about 3,000) who speak certain dialects of Romanian. (see Kontra, 1997). Results of the recent comprehensive survey of the Roma in Hungary confirm that in the Hungarian educational system, the gap between Roma and non-Roma population has grown. "Nationwide, $88 \%$ of 3-5-year-olds attend kindergarden, but attendance for Roma children is only $42 \%$. Causes include lack of facilities, available places and equipment - and ever-present discrimination. Although $82.5 \%$ of young Roma aged 20-24 years have finished 8 years of elementary school, a considerable portion of them did so belatedly. In $2000,5 \%$ of all 16 -year-olds nationwide failed to complete elementary school; for young Roma in 2003, the drop-out rate from elementary school was 36\%. Between 1993 and 2003, the number of Roma children classified as mentally handicapped and therefore sent to so-called "auxiliary schools" increased. Approximately $20 \%$ of school-age Roma children attend such special schools and classes. In 2001, the nationwide ratio of all children entering secondary school was $73 \%$, whereas only a fifth of Roma children get to study in secondary school.“ (Kemény et al., 2004; Wizner, 2005). 


\section{The Sociolinguistic Survey Project}

\section{Main Objectives}

In academic as well as in public discourse in Hungary, there is a fear that the existence of 'small' languages is endangered. This applies to minority languages, too. The 13 indigenous minority communities are all currently undergoing the process of shifting from their language to the majority language. In order to be able to create a strategy to reverse language shift for each of these communities, current sociolinguistic processes, as well as attitudes of the minorities to their own languages and communities first have to be explored.

Our sociolinguistic survey 'Dimensions of linguistic otherness: Prospects of minority language maintenance in Hungary' (National Research \& Development Programme 5/126/2001) was devised in order to develop powerful multidisciplinary comparative research methodologies and tools, which would have predictive power with respect to future linguistic assimilation processes. It also gave a detailed analysis of the dynamics and local models of language shift and maintenance focusing on the process of language shift (see Bartha, 2003).

\section{Data Collection}

Defined samples were used in each community in the present research. Informants were chosen according to age and sex, in three educational groups (lower, middle, and high qualifications). The three age groups in the six minority communities were: 20 to 40 -yearolds (young), 41 to 60-year-olds (middle-aged) and 61 to 80 -year-olds (elderly). In all the three age groups, people with both lower and middle-level qualifications were represented. University graduates were only examined in the middle-aged group. Out of the 70 informants in each community, there were 35 males and 35 females.

Data was collected using the same questionnaire containing 142 questions, compiled by the authors. The questionnaire includes the following modules:

I. General part (information about the subject)

II. Language use, language choice

III. Knowledge of languages, subjective opinions about language(s) (subjects' own command of languages, linguistic abilities)

IV. Stereotypes, prejudices 
In the questionnaires used during the field work, there were several questions about how the respective communities defined their identity. In this paper, however, we focus principally on the answers to the following six questions.

- What is your nationality? (Q 14)
(1) Romanian/Serbian/Slovakian/German/Romani/Boyash
(2) Romanian/Serbian/Slovakian/German/Romani/Boyash and Hungarian
(3) Hungarian

- What is your mother tongue? (Q 15)
(1) Romanian/Serbian/Slovakian/German/Romani/Boyash
(2) Romanian/Serbian/Slovakian/German/Romani/Boyash and Hungarian
(3) Hungarian

- What did you declare as your nationality in the 2001 census? [Do not read out the answers!] (Q 98)
(1) Romanian/Serbian/Slovakian/German/Romani/Boyash
(2) Hungarian
(3) I don't remember

- What did you declare as your mother tongue? [Do not read out the answers!] (Q 99)
(1) Romanian/Serbian/Slovakian/German/Romani/Boyash
(2) Hungarian
(3) I don't remember

- What makes you feel Romanian/Serbian/Slovakian/German/ Romani/Boyash? [Read out the answers from 1 to 4 and let the informant choose one!] (Q 23)
(1) My parents
(2) It is my mother tongue
(3) This is the language I speak
(4) I belong to this community

- Which language do you consider more useful? Romanian/ Serbian/Slovakian/German/Romani/Boyash or Hungarian? (Q 70)
(1) Romanian/Serbian/Slovakian/German/Romani/Boyash
(2) Hungarian
(3) Both
(4) I don't know 
The questionnaire was translated into, and administered in, the local variants of the respective minority language. The sessions were tape recorded, in order to keep subjects' comments as well as to create a voice archive of minority languages in Hungary. The data set was processed using the statistical program MiniStat (see Vargha, 2000; Vargha \& Czigler, 1999).

\section{Language and Ethnic Identity-Some Comparative Data}

In many European countries, including Hungary, linguistic problems, conflicts and repression arise from nation-building projects. Hence, in the 'classic philosophical matrix' of the nation state, language is one of the primary instruments of political leaderships in establishing their legitimacy (Dorian, 1998; May, 2001; Wright, 1997). However, it is important to underline that national and ethnic identity, a keynote in terms of the majority-minority relation of a given state, is not necessarily static. Different social identities of individuals and feelings of belonging to groups are a matter of complex relations. Within these diverse relational systems the connection of language/mother tongue and identity, as well as the roles attributed to languages, can differ considerably from each other, just as different linguistic practices can co-exist within a given community.

Language is inevitably a crucial group marker in many cultures: it indicates detachment from other groups, thus being at the same time the means and result of the construction of the 'us and them' opposition (see Joseph, 2004; Wright, 1997), whereas one-to-one mapping between national and ethnic identity always expresses the majority perspective that exercises power, representing in principle the congruence of nation, state and language. It is now widely accepted, however, that these notions need to be separated if real linguistic (and ethnic) arrangements are to be understood. Therefore, in our survey we aimed at studying the architecture of the 'Boyash, German, Roma(ni), Romanian, Serbian, Slovakian identity' and the role of the minority language in the construction and negotiation of identities.

Figure 5 indicates the proportions of informants who consider their language to be the minority language, both languages, or Hungarian (see Q15). Figure 6, on the relationship between linguistic and national identification, shows that, in five cases, the value for national minority identification exceeds that for linguistic minority identification (see Q14 and Q15). 


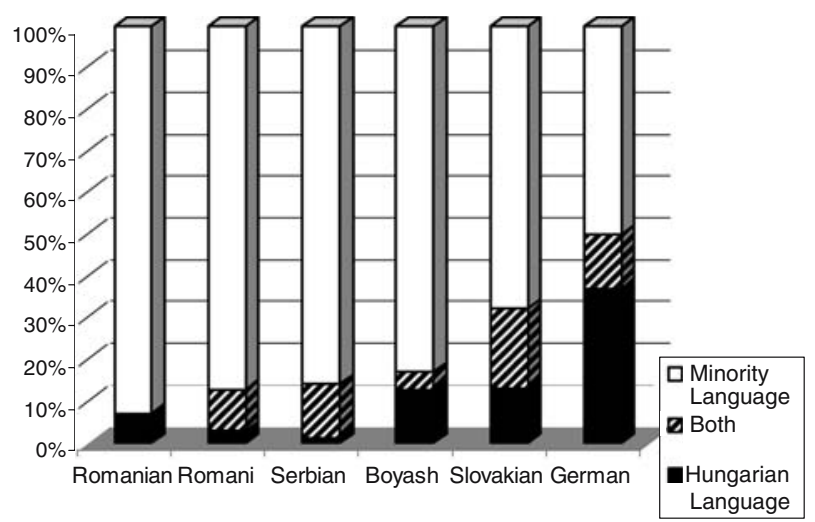

Figure 5. What is your mother tongue? $N=420(\mathrm{Q} 15)$.

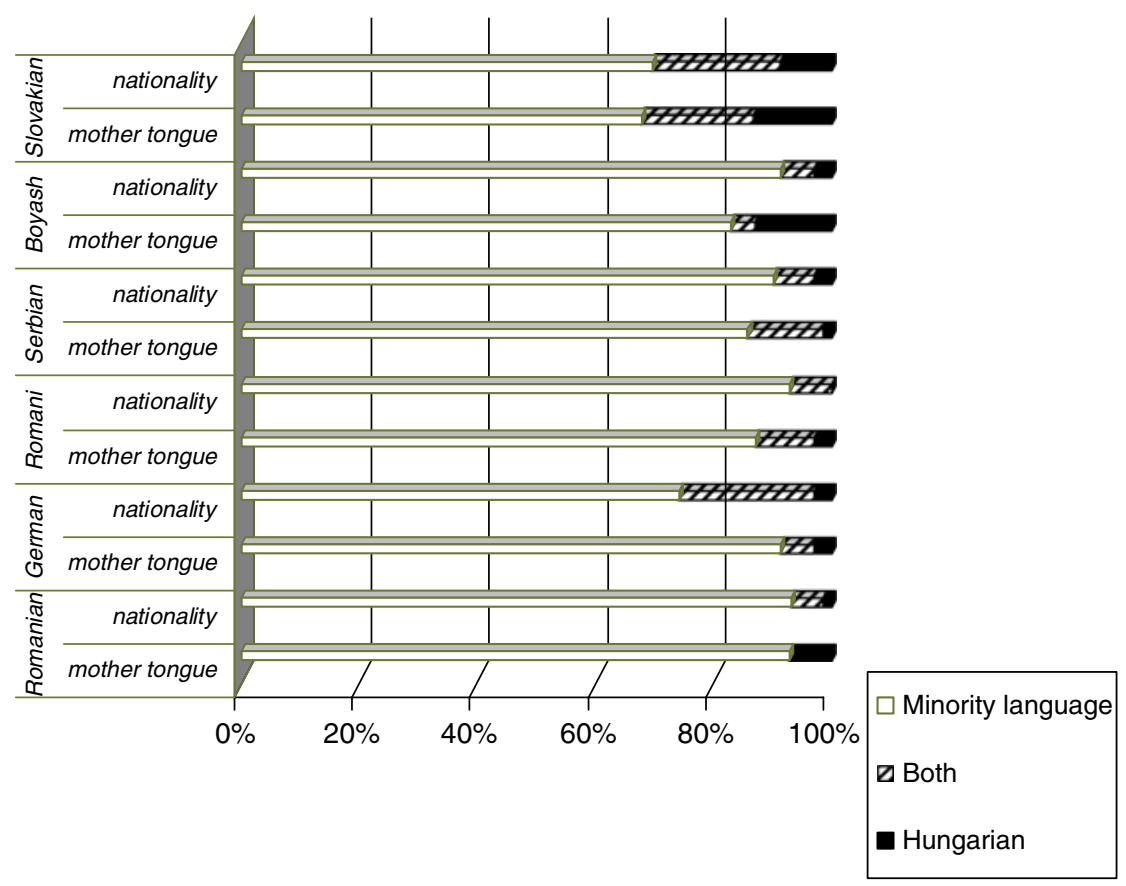

Figure 6. What is your nationality? (Q14) What is your mother tongue? (Q15) $N=420$.

It is clear that judgments about the components of identity are not homogeneous within the six examined communities. For example, Romanian and Slovakian informants consider mother tongue to be of great importance, while the function of the native language in identity construction is fundamentally different within the 


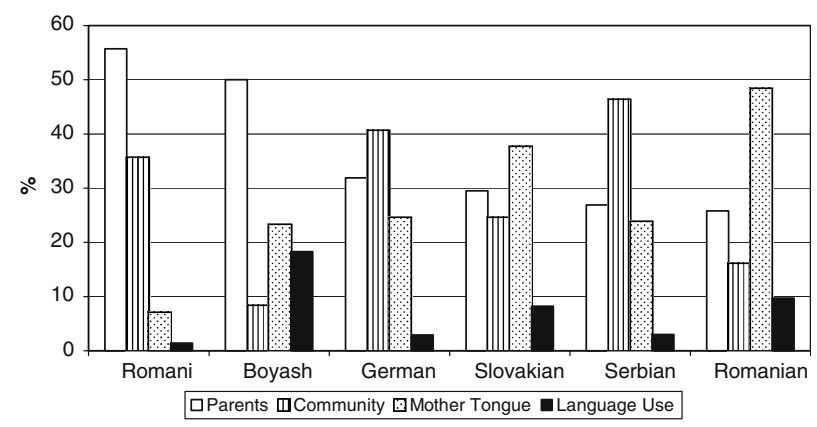

Figure 7. Components of ethnic identity in six communities $N=420$ (Q23).

Romani and Boyash communities from the role other (national) minority languages play in our survey (see Q 23, Figure 7).

The explanation for this second result is to be found in multiple internal (community-related) and external (mainstream societyrelated) factors. The present study cannot analyze this question in detail; we shall highlight only two of the reasons mentioned. The situation is very complex both in linguistic and in cultural terms, since the Hungarian Roma community can be divided into three major linguistic groups. One of these groups does not speak the Romani language (Romungro population), whereas the other two communities (Romani and Boyash) use different dialects of these mutually unintelligible languages in their everyday communication. Another important sociolinguistic fact is that most of the speakers with Romani/Boyash as their first language are now bilingual. Moreover, this proportionally most populous linguistic-ethnic minority in Hungary is sociologically at least as diverse as linguistically. Consequently, the Romani/Boyash and Hungarian languages have completely different symbolic meanings in these groups, as the two languages in contact will have different roles in constructing identities, too.

The fact that conceptualizing the largest minority in Hungary on an ethnic-linguistic-cultural basis was non-existent before 1990 has great importance, too. Today, despite the existing legal framework declaring Roma an ethnic minority, there are different social, political and ideological practices amongst both researchers and policymakers in terms of whether 'the Roma issue' should be approached as a social or as an ethnic problem ${ }^{10}$. This controversial situation is

\footnotetext{
10 The ethnic approach acknowledges the existence of a separate Roma culture and calls for efforts to preserve and develop their customs, traditions and language, which is what the supporters of this view mean by integration.
} 
indicated by the first version of the Minority Act (see note 5), as well as by the '(non-)connection' of the European Charter for Regional or Minority Languages countersigned by Hungary in 1995 and the Romani/Boyash languages ${ }^{11}$.

In the next section, we present data on the attitudes of the Romanian and the Serbian groups to their mother tongues and nationality in order to illustrate a kind of predictive value of crosscommunity analysis in terms - at least - of intensity of the language shift process on the one hand, and the way changes in politicalideological order and symbolic market values influence speakers' self-perception, on the other.

In order to give a detailed description of identity and language otherness of the Romanians in Hungary, we selected the Romanian community of Kétegyháza. Serbians are represented here by the Serbs of Pomáz. The fieldwork done in the Romanian community was completed by Maria Abrudán, a primary school teacher, and in the Serbian community by Mrs. Milos Simics, a secondary school teacher.

\section{Research Questions}

We focus here on the question of similarities and differences in the specification of the minority identities of Romanians and Serbians in Hungary. To be more specific, we shall examine whether the survey suggests that attachment to the Romanian/Serbian mother tongue or attachment to the Romanian/Serbian nationality is stronger. The primary reason for choosing these two communities for comparison is that they are both Greek Orthodox, a religion that kept the languages the communities had been using for centuries-Romanian and Old Church Slavonic, respectively - up to the present day. We could contrast this with other minorities, such as Catholic Germans or Croatians, where the language of the Church is Hungarian, the official language of the country. (See Kontra (1997: 1714) with respect to Croatians and Manherz (1998: 30) with

${ }^{11}$ Hungary was one of the first countries to sign the European Charter for Regional or Minority Languages (1992) and the related acts were enacted by Parliament in 1995. The protection of minority languages was at this point extended to the whole of Hungary, but only for six languages, Romani not included. The Charter states that if there is a sufficient number of students, instruction carried out in minority languages should be supported from pre-school to secondary school, and the teaching of these languages should be incorporated into the curriculum. It seems, however, that the Roma in Hungary have not been granted this opportunity-either before or after the political changes. 
respect to Germans, discussing the negative effect of this factor on minority language maintenance.) Beside language use, the Greek Orthodox Church has deliberately helped maintain the identity of minority communities: with religious traditions, schools (with religion classes after secularization), and other programmes. In answering our research questions, we can rely on two types of statistical databases. The first database is derived from the questions in the national census of 2001 about the mother tongue and nationality of minorities registered by the Hungarian Central Statistical Office (see Népszámlálás 2001, 2002; Q23.1 and Q23.3) and the second is the National Research \& Development Programme 5/126/2001 database (Q14, Q15, Q23, Q70, Q98, Q99).

\section{Results}

\section{Romanian and Serbian identity according to the data of the 2001 census}

We have processed the data of two questions in the questionnaire of the 2001 census (see Népszámlálás 2001, 2002, Appendix). The two questions are the following:

- Which nation do you feel you belong to? (Q 23.1)

- What is your mother tongue? (Q 23.3)

From the data of the 2001 census related to the Romanian and Serbian minorities in Hungary, we present the overall (country) data and, for each minority, those of the two counties whose population includes the highest number of Romanians (Békés and Hajdú-Bihar) and Serbians (Pest and Csongrád), respectively (see Figures 8, 9). According to the data for the whole country, there are more Romanians in Hungary who declare Romanian to be their mother tongue (8482) than those declaring their nationality to be Romanian (7995). With respect to Serbians, the situation is just the opposite: there are more people who declare their nationality to be Serbian (3816) than people who declare Serbian to be their mother tongue (3388). If we look at the county data under survey here, we see that the Serbians do not show any deviation in this respect; in both counties, there are more self-declared Serbian nationals (Pest: 884; Csongrád: 580) than people who give Serbian as their mother tongue (Pest: 749; Csongrád: 546). The difference in numbers between the Serbian nationals and those who declare their mother tongue to be Serbian is not high; there is not a single case where it exceeds $15 \%$. On the other hand, the county data for the 


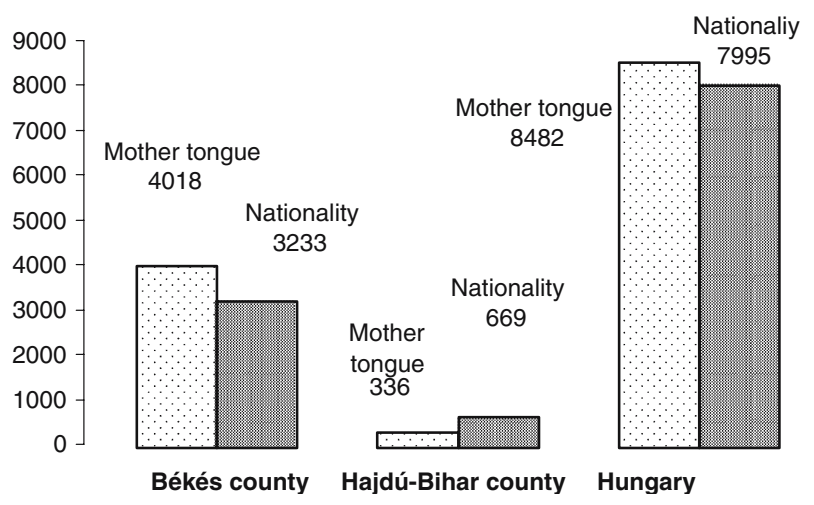

Figure 8. 2001 Census (Q23.1, Q23.3): the data for Romanians in Hungary (see Népszámlálás, 2001, 2002, pp. 204-222).

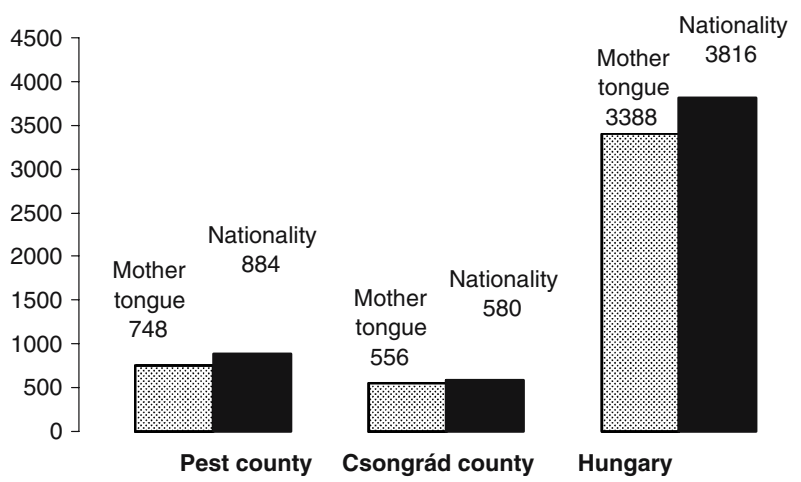

Figure 9. 2001 Census (Q23.1, Q23.3): the data for Serbians in Hungary (See Népszámlálás, 2001, 2002, pp. 231-241).

Romanians show different trends, and there are larger differences between the number of Romanian nationals and those declaring their mother tongue to be Romanian. In Békés county, there were $20 \%$ more people who declared their mother tongue to be Romanian than people who declared their nationality to be Romanian. On the contrary, in Hajdú-Bihar county, those declaring their nationality to be Romanian numbered $50 \%$ more than those declaring their mother tongue to be Romanian. In view of the census data, then, two important questions emerge. First, is there a correspondence between the data of the 2001 census and of the fieldwork in 2003? And secondly, what can be the reason for the serious discrepancy between the data on mother tongue and that on nationality? 
Romanian and Serbian identity according to the field work in 2003 In total conformity with the data of the 2001 census, there were $10 \%$ more Romanian informants who declared their mother tongue to be Romanian during the fieldwork than reported their nationality to be Romanian (see Figure 10). On the other hand, there were $7 \%$ more Serbian informants who declared their nationality to be Serbian than gave their mother tongue as Serbian . Our sample of 2003 proves, too, that it is primarily their mother tongue that determines the minority identity of the Romanians (especially in the case of Romanians living in Békés county), whereas the majority of Serbians express their Serbian identity more characteristically with their Serbian nationality.

While processing Question 14 (What is your nationality?), it turned out in calculating stochastic superiority that there is a significant difference between the Romanian and Serbian group: a significantly higher percentage of the informants belonging to the Romanian nationality declared themselves to be Hungarian than the Serbians did (Brunner-Munzel test: $\mathrm{BM}=2.018$, df $=105$, $P<.05)$.

According to their own recollections, both the Romanian and the Serbian informants identified themselves in the same way in the 2001 census and in the 2003 fieldwork. In this case, too, the Romanians gave more weight to the Romanian mother tongue, whereas the Serbians attached more importance to the Serbian nationality (Figure 11).
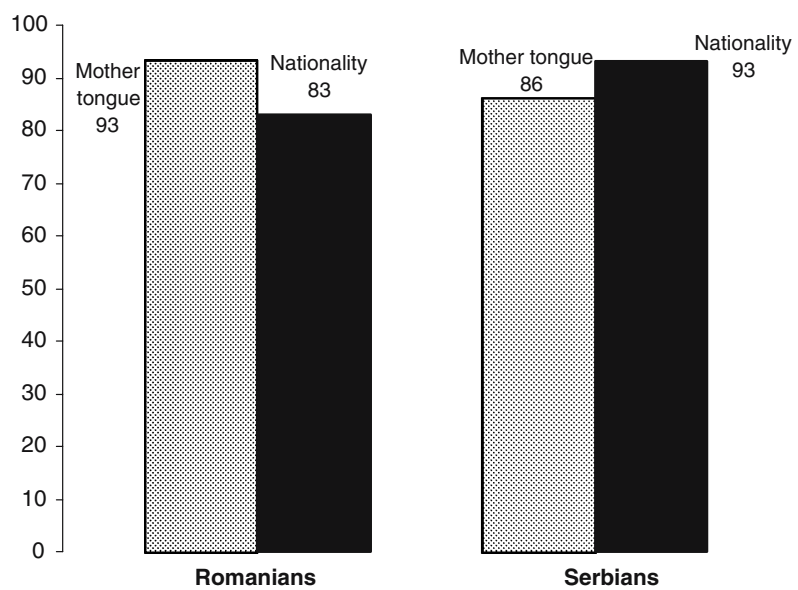

Figure 10. What is your nationality? (Q14) What is your mother tongue? (Q15). 

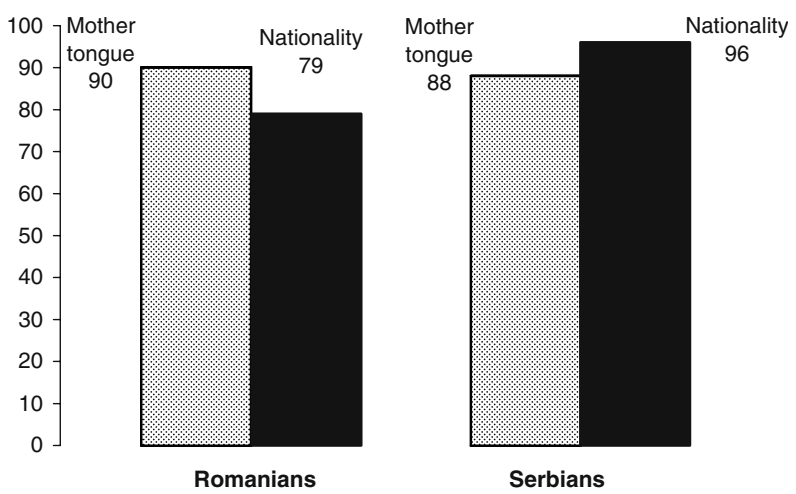

Figure 11. What did you declare as your nationality in the census in 2001? (Q98) What did you declare as your mother tongue in the census in 2001? (Q99).

What we wanted to find out by Question 23 was why Romanian informants declared themselves Romanian, and why Serbian informants declared themselves Serbian. For the best comparison of the answers, we gave four answer choices. Almost half (48\%) of the Romanians answering the question declared themselves Romanian because of their Romanian mother tongue, while it was more important for only $16 \%$ of the subjects that they belonged to the Romanian community. On the contrary, almost half $(46 \%)$ of the Serbian informants declared themselves Serbian because they belonged to the Serbian community, and only $24 \%$ of them answered that their Serbian mother tongue determined their choice (see Figure 12).

\section{Summary of Results}

Both the data collected in the 2001 census and the data collected in the fieldwork in 2003 demonstrate that the Romanians and the Serbians express their minority attachment in different ways. So, our hypothesis that the Greek Orthodox Church affected both communities similarly in experiencing their minority identity has proved wrong. To reinforce this conclusion, Hungarian minority communities that do not share the same religion as the Romanians and the Serbians should be examined.

It turned out in our research in 2003 that the Romanians express their Romanian identity by preference through their association with the Romanian mother tongue, while the Serbians are likely to express their identity by their connection to the Serbian nationality. 

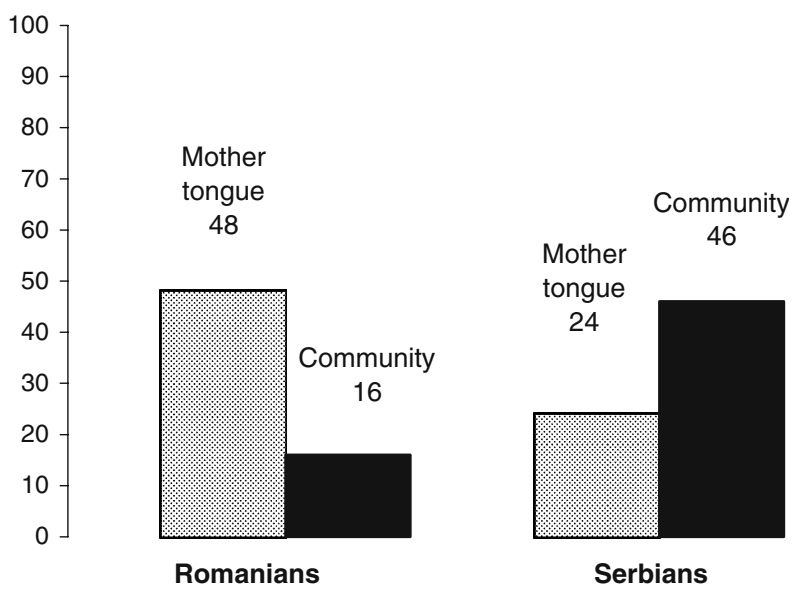

Figure 12. Why do you declare yourself a Romanian? (Q23) Why do you declare yourself a Serbian? (Q23).

Regarding the census data, the results within the Romanian community in the two counties examined are significantly divergent; that is, in Békés county, the number of people claiming Romanian as their mother tongue exceeds the number of people claiming Romanian nationality by $20 \%$. On the contrary, the data in Hajdú-Bihar is just the opposite; there are $50 \%$ more who declare themselves Romanian than those who declare their mother tongue to be Romanian. According to the results so far (see Borbély, 2001), therefore, language shift is not as advanced in the Romanian communities in Békés county as it is in the Romanian communities in Hajdú-Bihar county. So the divergence between the data of mother tongue and nationality reflects different stages of Romanian-Hungarian language shift. The more pronounced the deviation is between the data of the Romanian mother tongue and Romanian nationality, the more advanced Romanian-Hungarian language shift is.

According to the results shown in our analysis, we can advance the following hypotheses for our further research:

(a) With respect to the connection between the data relating to the mother tongue and the nationality of a minority community, we can point out that the larger the deviation between the data is, the more likely it is that the community is in an advanced stage of language shift from the minority language to the majority language. 


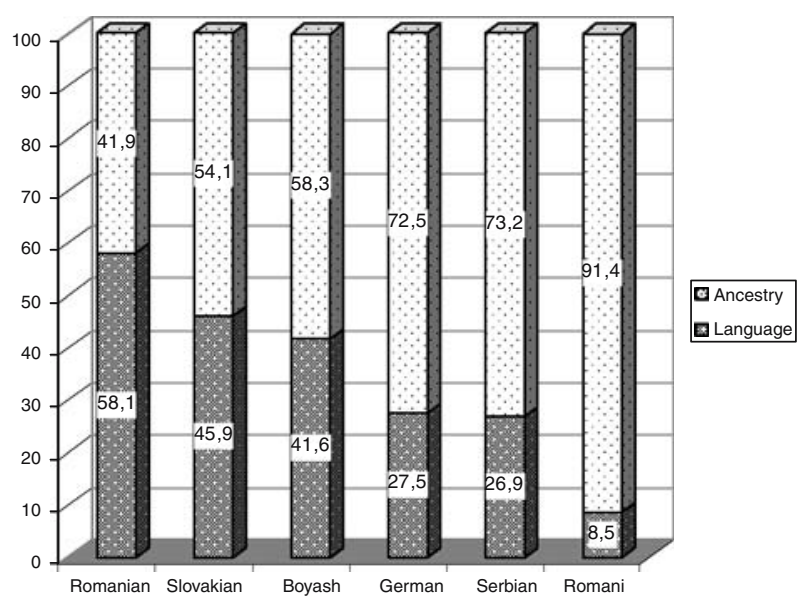

Figure 13. The role of language and ancestry in identity construction $N=420$ (Q23).

(b) Conversely, the less the deviation between the data relating to the mother tongue and the nationality is, the more likely it is that the community maintains its minority mother tongue and identity.

(c) According to the results, it can be hypothesized that if a Romanian person in Hungary loses his/her native language, then his/ her Romanian identity will be lost as well (see Borbély, 2001: 184). But if a Serbian person in Hungary loses her/his native language, he/she will not lose the Serbian identity as rapidly as a Romanian, because of his/her strong experience of belonging to the Serbian community.

\section{Concluding Remarks}

Ethnic identity, as well as the relationship between language and ethnicity, carries different meanings within the communities, where the Herderian, nationalist ideology of language, the strong relationship between language and identity, has different impacts on the speech communities studied. Serbians and the Romani group have very similar ideas on the role mother tongue can play in negotiating identities (Figure 13$)^{12}$ : it does not seem to be the primary component of their identity. It has been proven by the analysis of cross-community

\footnotetext{
12 In order to make the total proportion of the minority language among components of identity more visible, 'language' in Figure 13 indicates combined data on 'mother tongue' and 'language use' whereas 'ancestry' means percentage values of 'parents' and 'community' together.
} 
differences that, as Woolard claims, "simply using language in particular ways is not what forms social groups, identities, or relations (nor does the group relation automatically give rise to linguistic distinction); rather, ideological interpretations of such uses of language always mediate these effects." (Woolard, 1998: 18)

Results of the cross-community analysis indicate that Serbian and Romani languages are fairly safe in the internal linguistic market, although education level and socio-economic status correlate negatively with the degree of speakers' language preservation efforts. In the external linguistic market the instrumental value of the minority language is the highest in the case of the German community (see Figure 14). However, language shift has been taking place in all of the six communities.

Joining the EU will obviously influence the future of specific minority languages of Hungary in different ways. Apart from their symbolic role, the remarkable social and economic importance of languages and language use cannot be ignored. The complementary status of the languages in several countries of the region will mean that languages becoming official in the EU will be relatively upgraded, whereas in the case of speakers of other minority languages social and economic marginalization will increase. In the comparative frame among nations the notion of national and ethnic identity will inevitably be recontextualized; the meaning of the idea of the nation will be reformulated to include new elements not only in a political, but in an ethno-cultural sense as well. Individuals and groups will have to define themselves not only in terms of majority-minority, but also in terms of minority-minority on the one hand, and Hungarian citizen-European citizen, as well as national identity-European identity on the other hand.

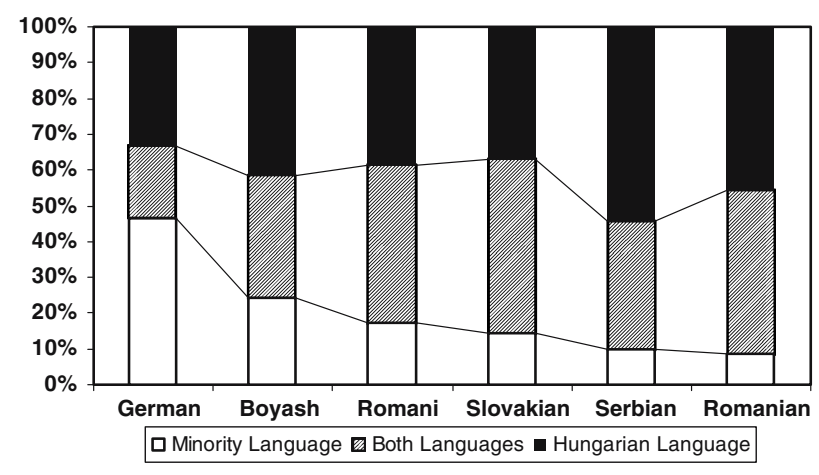

Figure 14. Usefulness of languages $N=420$ (Q 70). 
Comparative analysis of various language shift arrangements, linguistic practices, attitudes, ideologies, and especially diverse identity constructions of the different linguistic minorities in our project makes it clear that the identification of community-specific factors not only broadens our understanding of language shift dynamics, but also makes it easier to determine the appropriate strategies, techniques and technologies proposed to reverse or decelerate the process. Some consider language maintenance the result of conscious policy action and planning activities of individuals, groups or organizations. Practice, however, demonstrates that organised movements directed from the top level are not successful in themselves, but only if accompanied by wide socialcommunal support (Fishman, 1991, 2001; Hyltenstam \& Stroud, 1996).

\section{AcKNOWLEDGEMENTS}

This research was supported by Nemzeti Kutatási és Fejlesztési Programok [the National Research \& Development Programme] 5/ 126/2001, by the European Commission Contract No 029124 (CIT6) SSA, by Bolyai János Kutatási Ösztöndíj [Bolyai János Research Fellowship] BO/00332/02, and by Országos Tudományos Kutatási Alapprogramok [Hungarian Scientific Research Fund] M45689. The authors wish to express their thanks to András Vargha for conducting statistical analyses for this research with the MiniStat statistical program package. Our thanks are also due to Patrick Stevenson for the attention he paid to the paper during the editing process, and to our colleagues Andrea Szőnyi and Judit Kuti for their useful comments on a previous version of this paper.

\section{REFERENCES}

Act LXXVII on the Rights of National and Ethnic Minorities (1993) Budapest: Hungarian Parliament. http://archiv.meh.hu/nekh/Angol/93LXXVIIkistv.htm (Official version: 1993. évi LXXVII. Törvény a nemzeti és etnikai kisebbségek jogairól Magyar Közlöny 1993. július 22.)

Bartha, C. (1999). A kétnyelvüség alapkérdései. Beszélők és közösségek [Fundamental questions of bilingualism: Speakers and communities]. Budapest: Nemzeti Tankönyvkiadó.

Bartha, C. (2003). Die Möglichkeiten der Bewahrung der Minderheitensprachen in Ungarn. Über eine soziolinguistische Zweisprachigkeitsuntersuchung im Landesmassstab [Possibilities of maintenance of minority languages in Hungary. On a 
national sociolinguistic survey on bilingualism] In Ferenc Glatz (Ed.), Sprache und die kleinen Nationen Ostmitteleuropas (pp. 225-236). Budapest: Europa Institut.

Bartha, C. \& Borbély, A. (1995). The influence of age and gender on code-switching among Romanians in Hungary. In Durk Gorter (Ed.), Summer School CodeSwitching and Language Contact. Ljouwert/Leeuwarden, 14-17 September 1994 (pp. 284-289) Ljouwert/Leeuwarden: Fryske Akademy.

Borbély, A. (2001). Nyelvcsere. Szociolingvisztikai kutatások a magyarországi románok közösségében [Language shift: sociolinguistic investigations in the community of Romanians in Hungary]. Budapest: Készült az MTA Nyelotudományi Intézetének Élőnyelvi Osztályán.

Borbély, A. (2002). Néhány adat a magyarországi románok nyelvi jogairól [Remarks on the language rights of Romanians in Hungary]. In M. Kontra \& H. Hattyár (Eds.), Magyarok és nyelvtörvények [Hungarians and language laws] (pp. 61-72). Budapest: Teleki László Alapítvány, A Magyarságkutatás könyvtára XXVI., Készült az MTA Nyelvtudományi Intézetének Élőnyelvi osztályán.

Bozóki, A., Körösényi, A. \& Schöpflin, G. (1992). Post-communist transition: Emerging pluralism in Hungary. London: Pinter Publishers, New York: St.Martin's Press.

Commission Report: 2002 Regular Report on Hungary's Progress towards Accession COM (2002) 700 final Date: Brussels, 9.10.2002 SEC(2002) 1404 http://www.fifoost.org/ungarn/EU_Hungary_2002/EU_Hungary_2002.php.

Constitution of the Republic of Hungary (Act XX of 1949) http://www.parlament.hu/alkotmany/constitution.htm .

Czibulka, Z. (Ed.) (1991). 1990. évi népszámlálás. A nemzetiségi népesség száma egyes községekben (1960-1990) [Census of 1990: The size of nationality groups in villages (between 1960 and 1990)]. Budapest: Központi Statisztikai Hivatal.

Dorian, N. C. (1981). Language death. The life cycle of a Scottish Gaelic Dialect. Philadelphia: University of Pennsylvania Press.

Dorian, N. C. (1998). Western language ideologies and small-language prospects. In L. A. Grenoble \& L. J. Whaley (Eds.), Endangered languages: Language loss and community response (pp. 3-21). Cambridge: Cambridge University Press.

Erb, M. \& Knipf, E. (1999). A magyarországi németek körében végzett nyelvismereti felmérés tanulságai [Results of linguistic research conducted in the German minority community living in Hungary]. Kisebbségkutatás, 8.2: 176-187.

European Commission 2005. Euromosaic III. Regional and minority languages in the new Member States. http://europa.eu.int/comm/education/policies/lang/languages/langmin/euromosaic/synthesis_en.pdf Official Journal C 364, 18.12.2000.

Fase, W., Jaspaert, K. and Kroon, S., (Eds.) (1992). Maintenance and loss of minority languages. Amsterdam: John Benjamins.

Fishman, J. A. (1991). Reversing language shift: Theoretical and empirical foundations of assistance to threatened languages. Clevedon: Multilingual Matters.

Fishman, J. A. (Ed.) (2001). Can threatened languages be saved? Reversing language shift, revisited: A 21st century perspective. Clevedon: Multilingual Matters.

Gal, S. (1979). Language shift: Social determinants of linguistic change in bilingual Austria. New York, San Francisco, London: Academic Press.

Gal, S. (1993). Diversity and contestation in linguistic ideologies: German speakers in Hungary. Language in Society, 22: 337-359.

Gal, S. (1995). Cultural bases of language use among German-speakers in Hungary. International Journal of the Sociology of Language, 111: 93-102. 
Gal, S. (1996). Language shift. In H. Goebl, P. H. Nelde, Z. Starý, \& W. Wölck (Eds), Kontaktlinguistik/Contact Linguistics/Linguitique de contact. 1. Halbband/ Volume $1 /$ Tome 1 (pp. 586-594). Berlin, New York: Walter de Gruyter.

Gal, S. (2006). Minorities, migration and multilingualism: Language ideologies in Europe. In C. Mar-Molinero \& P. Stevenson (Eds), Language ideologies, policies and practices : Language and the future of Europe. Basingstoke: Palgrave.

Garami, E. \& Szántó, J. (1992). Magyarországi szlovákok identitása [The identity of Slovaks living in Hungary]. Regio.Kisebbségi Szemle, 2: 113-134.

Gyivicsán, A. (1993). Anyanyelv, kultúra, közösség. A magyarországi szlovákok [Mother tongue, culture, community: The Slovaks living in Hungary]. Budapest: Teleki ldizló Alapítvány.

Győri Szabó, R. (1998). Kisebbségpolitikai rendszerváltás Magyarországon [Minority policy in Hungary after the period of the regime change (1989)]. Budapest: Osiris.

Hyltenstam, K., \& Stroud, C. (1996). Language maintenance. In H. Goebl, P. H. Nelde, Z. Starý, \& W. Wölck (Eds), Kontaktlinguistik/Contact Linguistics/ Linguistique de Contact: Ein internationales Handbuch zeitgenössischer Forschung/ An International Handbook of Contemporary Research/Manuel international des recherches contemporaines. Vol 1 (pp. 567-579). Berlin, New York: Walter de Gruyter.

Joseph, E. J. (2004). Language and identity: National, ethnic, religious. Basingstoke: Palgrave Macmillan.

Karády, V. (1990). Egyenlőtlen elmagyarosodás, avagy hogyan vált Magyarország magyar nyelv országgá? Történelmi-szociológiai vázlat [Unbalanced Magyarization, or how Hungary became a monolingual country: Historical and sociological sketch]. Századvég, 2: 5-35.

Kemény, I., Rupp, K., Csalog, Z. \& Havas, G. (1976). Beszámoló a magyarországi cigányok helyzetével foglalkozó, 1971-ben végzett kutatásról [Research Report on the situation of the Roma living in Hungary (in 1971)]. Budapest: MTA Szociológiai Kutató Intézetének kiadványai.

Kemény, I., Janky, B. \& Lengyel, G. (2004). A magyarországi cigányság 1971-2003 [The Roma in Hungary between 1971 and 2003]. Budapest: Gondolat.

Kontra, M. (1997). Hungary. In H. Goebl, P. H. Nelde, Z. Starý, \& W. Wölck (Eds), Kontaktlinguistik/Contact Linguistics/Linguitique de contact 2. Halbband/Volume 2/ Tome 2 (pp. 1708-1722). Berlin, New York: Walter de Gruyter.

Kulick, D, (1992). Language shift and cultural reproduction. Socialization, self, and syncretism in a Papua New Guinean village. Cambridge: Cambridge University Press.

Manherz, K., (Ed.) (1998). A magyarországi németek [Germans living in Hungary]. Budapest: Útmutató Kiadó.

May, S. (2001). Language and minority rights: Ethnicity, nationalism, and the politics of language. London, New York: Longman.

Népszámlálás 2001, 4. Nemzetiségi kötődés, A nemzeti, etnikai kisebbségek adata [Census of 2001: Nationality attachments: The national and ethnic minority groups' data]. (2002). Budapest: Hungarian Central Statistical Office.

Réger, Z. (1979). Bilingual Gypsy children in Hungary: Explorations in the 'natural' acquisition of a second language. International Journal of the Sociology of Language, 19: 59-82.

Roma Education Working Group (2001). Research on Selected Roma Education Programs in Central and Eastern Europe. Final Report. Budapest: Open Society Institute. 
Seton-Watson, R. W. (1908). Racial Problems in Hungary. London: S. Constable. Spolsky, B. (2004). Language policy. Cambridge: Cambridge University Press.

Tóth, Á. \& Vékás, J. (2004). A 2001. évi népszámlálási adatok rövid összefoglalása [Short presentation of the data from the Census of 2001]. Barátság, 5: 4425-4432. Vargha, A. (2000). Matematikai statisztika pszichológiai, nyelvészeti és biológiai alkalmazásokkal [Mathematical statistics with applications in psychology, linguistics and biology]. Budapest: Pólya Kiadó.

Vargha, A. \& Czigler, B. (1999). A MINISTAT Statisztikai Programcsomag 3.2 verzió [The MiniStat Statistical Program Package, Version 3.2.]. Budapest: Pólya Kiadó.

Vermeersch, P. (2004). Minority policy in Central Europe: Exploring the impact of the EU's enlargement strategy. The Global Review of Ethnopolitics, 3.2: 3-19.

Vizi, B. (2003). Az Európai Unió és a kisebbségi nyelvek [The European Union and the minority languages]. In N. Orsolya, S. László (Eds), Nyelvi jogok, kisebbségek, nyelvpolitika Közép-Kelet-Európában [Linguistic Rights, Minorities, Language Policy in Central-Eastern-Europe] (pp. 37-56). Budapest: Akadémiai Kiadó.

Wizner, B. (2005). The figures of deprivation. The Hungarian Quarterly, 46.179, http://www.hungarianquarterly.com/no179/12.html.

Woolard, K. (1998). Introduction: Language ideology as a field of inquiry. In B. Schieffelin, K. Woolard \& P. V. Kroskrity (Eds.), Language ideologies: Practice and theory (pp. 3-47). New York: Oxford University Press.

Wright, S. (1997). Language as a contributing factor in conflicts between states and within states. Current Issues in Language \& Society, 4.3: 215-237.

\section{ABOUT THE AUTHOR}

Anna Borbély is a Senior Research Fellow at the Research Institute for Linguistics of the Hungarian Academy of Sciences. She is also a scientific collaborator at the Research Institute of the Romanian Minority in Hungary. Her primary research interests are in the fields of sociolinguistics and bilingualism. Address for correspondence: Research Institute for Linguistics, Hungarian Academy of Sciences, Benczúr utca 33, H-1068, Budpest, Hungary.

Csilla Bartha is Associate Professor at Eötvös Loránd University, Budapest and a senior research fellow at the Research Institute for Linguistics of the Hungarian Academy of Sciences. Her research and teaching interests include sociolinguistics, bilingualism, especially language shift and revitalization of minority languages, language policy, discourse analysis. E-mail: bartha@nytud.hu 